\title{
Using Clickers to Support Information Literacy Skills Development and Instruction in First-Year Business Students
}

\author{
Adrian Stagg and Michael Lane \\ University of Southern Queensland, \\ Toowoomba, Queensland, Australia
}

\section{Adrian.Stagg@usq.edu.au; Michael.Lane@usq.edu.au \\ Executive Summary}

Course-integrated information literacy (IL) instruction can be enhanced via the use of student response devices, or 'clickers'. The first phase of this study focused on how first-year undergraduate students perceived the use of clickers as a mechanism to encourage active learning and engagement in order to establish a baseline of information seeking behaviour and to actively engage students in the learning process. Data collected within IL classes and subsequent surveys of student perceptions are examined with discussion on the implications for future practice and research. Our findings from this first phase of this study through the quantitative data collected with clickers indicate that first year business students have shortcomings in information literacy and can improve their information literacy skills in relation to research and assignment work in their formal assessment. Furthermore the use of clickers are positively viewed by undergraduate students and postgraduate students as a technology which can facilitate active learning and engagement if used appropriately with clearly aligned learning objectives.

Keywords: Information literacy, technology enhanced learning, clickers, active learning, cognitive overload, student response devices, student engagement.

\section{Introduction}

The development of information literacy skills in a discipline-specific context is a critical element contributing to students' academic success (Boudreau \& Bicknell-Holmes, 2003; Feast, 2003; Wu $\&$ Kendall, 2005), and confidence and retention (Goldfinch \& Hughes, 2007; Gross \& Latham, 2007; Oliver, 2008). Moreover information literacy is acknowledged as one of the critical attributes that employers require of Business graduates entering the workforce (Department of Education, Science and Training [DEST], 2007; Drucker (1995), cited in Wu \& Kendall, 2005; O'Donoghue \& Maguire, 2004). The main aims of this study were to (1) identify the baseline

Material published as part of this publication, either on-line or in print, is copyrighted by the Informing Science Institute. Permission to make digital or paper copy of part or all of these works for personal or classroom use is granted without fee provided that the copies are not made or distributed for profit or commercial advantage AND that copies 1) bear this notice in full and 2) give the full citation on the first page. It is permissible to abstract these works so long as credit is given. To copy in all other cases or to republish or to post on a server or to redistribute to lists requires specific permission and payment of a fee. Contact Publisher@InformingScience.org to request redistribution permission. level of information literacy in first year undergraduate business students; (2) to gather quantitative data regarding students' understanding of consistently difficult concepts in relation to information literacy and their written assignment work and (3) to gauge student perceptions of the use of clickers to facilitate their attention and active learning in information literacy classes. 
The structure of this paper is as follows: first we reviewed the empirical literature on information literacy, the use of clickers to facilitate active learning and identified what are perceived to be impediments in using clickers in classes. Next we described and justified the methodological approach deployed in this study. Then we presented and discussed the results of our data analysis regarding the use of clickers in information literacy classes for first year undergraduate business students. Last we presented our conclusions and implications of this study for existing knowledge and future work in the use of clickers to facilitate active learning and participation in undergraduate courses.

\section{Review of Background Literature for This Study}

\section{Information Literacy and the Business Student}

Information literacy (IL), is defined in the Australian and New Zealand Institute for Information Literacy (ANZIIL) Framework as the ability to

recognise a need for information, determine the extent of information needed, access information efficiently, critically evaluate information and its sources; classify, store, manipulate and redraft information collected or generated; incorporate selected information into their knowledge base [and] use information effectively to learn, create new knowledge, solve problems and make decisions. (Bundy, 2004, p. 3)

Essentially, an information literate person can locate information relevant to a particular need from an appropriate source, judge its quality and 'fit-for-purpose' and then apply the information to the need in an ethical manner. It obviously requires a level of critical thinking (Reece, 2007), and the underpinning principles need to be explicitly included in the curriculum. Information literacy skills are not merely the by-products (Johnston \& Webber, 2006) of a higher education degree (or any other level of education), but require a considered, integrated approach built on sound pedagogical practice (Kocevar-Weidinger \& Cooperstein, 2003; Weisskirch \& Silveria, 2007). The development and use of these skills are obviously not confined to the learning environment, but also applicable to workplace settings, especially as leveraging information represents a competitive advantage for business (Kikoski \& Kikoski, 2004). Information literacy has become critically important as work becomes increasingly knowledge based in modern economies.

\section{Clickers: What Are They?}

Clickers, or student response devices, are not a new technology. A review of existing literature indicates similar devices were used as early as the 1960's (Judson \& Sawada, 2002). Whilst the basic principle has remained unchanged, the devices have developed significantly with the advent of increased processing power of microprocessors and wireless telecommunication. Currently the system works by providing a specific communication channel between portable keypad devices usually referred to as a clickers, a USB receiver (hardware) using specific radio wave frequencies. Proprietary software manages the wireless communication between the clicker keypads and the USB receiver and integration of the clicker user interface data collection and reporting within Microsoft PowerPoint software. Users are presented with a question via a PowerPoint slide, with a range of answers which are designated a number or letter. Respondents then key the number or letter correlating to their answer, which, via the receiver, is collected and then tabulated. It is then possible to display the range of responses graphically. It is possible to assign a specific device to a student (and thus track a students' progress during the class individually), or to simply issue the devices anonymously. The software packages are usually able to generate reports at the 
end of each class, collating all received data, and offering a range of ways to cross-index answers. TurningPoint software and Keepad clicker devices were utilised in this study (Keepad Interactive, 2010).

\section{Using Clickers to Facilitate Active Learning}

Information literacy instruction can be effectively aligned with the principles of active learning. By situating the class within the discipline studied and linking the class to assessment the Librarian can build relevance for the class content (Campbell \& Norton, 2007), yet this is only half of the equation. Students also need to be engaged in practically applying the skills learned, and to use these basic principles as a foundation for deeper learning. In such an environment, students are able to transfer concepts to new situations, or use basic concepts to inform their own search and evaluation strategies (Jacobson \& Xu, 2004). The student moves from a passive recipient of information to an active participant in the learning process (Bergtrom, 2006, p. 106; Deleo, Eichholtz \& Sosin, 2009, p. 443; Dill, 2008), and can discuss their own experiences in the context of the class. Trees and Jackson (2007) note that active learning is made more difficult by larger classes. Clickers may mitigate some of the barriers to active learning in large classes using this method of teaching. It is far easier to fall into a traditional-lecture model and thus perpetuate a passive learning experience. Furthermore, the environment of large lecture theatres can reinforce student perceptions of their roles (passive recipients rather than key stakeholders) within the learning environment - clickers can create an atmosphere where participation is implicit and expected (Grimm, Soares, Agrawal, \& Law, 2007, p. 3287; Koppel \& Bereson, 2008, p. 3; Trees \& Jackson, 2007, p. 22). In larger classes, students may not feel able to contribute, or be willing to open themselves to possible ridicule (Grim et al., 2007, p. 3288). Within this type of learning, feedback is rarely offered (Trees \& Jackson, 2007, p. 23) (as limited vehicles exist for collecting student understanding and returning comments) and the communication in the learning process is a monologue rather than a dialogue. MacArthur and Jones (2008, p. 187) concur that use of clickers in large classes can be effective and create a more personal learning environment.

However, some students may be resistant to the paradigm shift as the expectation moves from passive recipient to active learner - as this contradicts their expectations of the learning environment (Trees \& Jackson, 2007, p. 25). Students may actually find that the larger, lecture style presentation is compatible with their learning style, and as such ascribe no value to the inclusion of clickers in the course (Trees \& Jackson, 2007, p. 37). Clickers will not appeal to all students, as some students have expressed that clickers add to their anxiety levels (Koppel \& Bereson, 2008, p. 9). Trees and Jackson (2007) argue for the clicker to instead be seen as a social tool, rather than an educational one, as successful integration into the classroom is reliant upon student acceptance (p. 38).

\section{Cognitive Load Theory}

Clickers are very simple for the end-user to master (Trees \& Jackson, 2007, p. 22), and this has been noted in some studies into student acceptance of, and attitude to, the use of clickers (Lincoln, 2007, p. 3329; MacArthur \& Jones, 2008, p. 192). There is substantial empirical data from previous studies to support the perception that generally students find clickers easy to use (Lincoln, 2007; MacArthur \& Jones, 2008; Trees \& Jackson, 2007).

Some research has been conducted into the impact of technology enhanced learning drawing on cognitive load theory, which can be applied to the clicker experience. The concern is that information presented in multiple formats may overload the learners' working memory and negatively impact on their ability to absorb the information (vanMerrienboar \& Ayres, 2005). This 'split attention effect' (vanMerrienboar \& Ayres, 2005, p. 7) can be compounded when the amount of information within the learning task exceeds the learners processing capabilities (Mayer \& Mo- 
reno, 2003, p. 45). The implication for clicker use in lectures, therefore is to balance the number of questions posed so that learners can focus on the content and skills, whilst also taking advantage of benefits of clicker inclusion (Jensen, Meyer, \& Sternberger, 2009)

\section{Advantages of Clicker Use}

Whilst it has been reported that clickers have mostly been utilised within the hard sciences, it is clear that there is an emerging trend of use in Business courses and Library instruction (Beatty, 2004; Caldwell, 2007; Collins, Tedford, \& Womack, 2008; Deleo et al., 2009; Dill, 2008; Koppel \& Berenson, 2008; Mula \& Kavanagh 2009). Traditionally, the perception has been that clickers facilitate only single-answer closed questions, but their use in peer instruction and class discussion (Bergtrom, 2006; Deleo et al., 2009; Hoffman \& Goodwin, 2006; Jensen et al., 2008) challenges this approach - indicating a paradigmatic shift towards active learning pedagogies.

The advantages most commonly reported show clear benefits to both students and academic staff, but only if certain conditions are met. As with all technology-enhanced learning, there is a danger in placing the technology before the learning which does not result in a value-adding proposition for the student experience.

\section{Using Clickers to Actively Engage Students in Classes}

Primarily, the use of clickers can result in an increase in student motivation to participate in class (Beekes 2006; Collins et al., 2008; Dill, 2008; Koppel \& Bereson, 2008; Lincoln, 2007; MacArthur \& Jones, 2008), coupled with the advantages of providing automatic feedback within the class. These have been explored in a limited fashion as they pertain to large cohorts (MacArthur \& Jones, 2008; Trees \& Jackson 2007), which has major implications for teaching and learning at the University of Southern Queensland. First-year core courses routinely have two- to threehundred on-campus students creating challenges for lecturers in achieving student engagement, facilitating knowledge development, and providing formative feedback.

\section{Using clickers effectively in classes}

Lecturers utilise Clicker technology at a number of key points during a class. They can be used to gauge existing levels of knowledge of foundational concepts (Caldwell 2007; Collins et al., 2008; Deleo et al., 2009), which can be useful in adjusting the presentation of the lecture, as well as identifying concepts with which students consistently grapple. Addressing these learning needs can be done at point-of-need, but also student feedback collected during a class regarding student understanding of key concepts and principles represent opportunities for a teacher to take a more strategic approach to course redevelopment (Collins et al., 2008).

Due to the instantaneous nature of the feedback, it is possible to implement interventions at the point of need (Hoffman \& Goodwin 2006; Lincoln 2007) or to establish that formative knowledge is constructed on sound understanding of the underpinning concepts (Bergtrom, 2006; Caldwell, 2007; Hatch, Jensen \& Moore 2005). This model of lecture delivery essentially means that the feedback is two-way - the students are able to indicate their level of understanding, and the lecturer is able to respond by addressing identified needs (Caldwell, 2007; Koppell \& Bereson, 2008; Trees \& Jackson, 2007). In this manner, the use of clickers supports building student confidence as they are able to receive feedback on their own learning, and are able to relate their level of learning and understanding to that of their peers (Perry, VandeKamp, Mercer, \& Nordby, 2002). In some cases (Perry et al., 2002) students have expressed relief when they realise that they are not the only one struggling to understand a lecture, and that this peer benchmarking is a key component to student confidence levels. 
Intertwined with this is the anonymity of responses (Caldwell, 2007; Grim et al., 2007; Hoffman \& Goodwin, 2006; Koppel \& Berenson, 2008; MacArthur \& Jones, 2008; Trees \& Jackson, 2007) which is linked to participation. Students have reported the anonymity to be an integral reason for using clickers, as they do not 'lose face' by admitting ignorance to their peers. Additionally, the anonymity mitigates some cultural factors inhibiting active participation such as competency in English language for students for whom English is not their first language. Whilst the technology is remarkably simple for the end-user (Lincoln, 2007; MacArthur \& Jones, 2008; Trees \& Jackson, 2007), there are pedagogical implications for academic staff wishing to pursue their use.

Clickers can be effectively used as a reflective tool in course redesign and constructive alignment (Collins et al., 2008; Dill, 2008; Hoffman \& Goodwin, 2006; Koppel \& Bereson, 2008; Simpson \& Oliver, 2006), as there needs to be clear links between the questions posed and the desired learning outcomes (Beatty, 2006; Tanner \& Allen, 2005). Simply placing the clickers into students' hands does not guarantee engagement (Hoffman \& Goodwin, 2006) as they need to be actively supporting the learning process.

From the design standpoint, the course content, not the technology needs to remain as the primary focus (Draper \& Brown, 2004). Lecturers have acknowledged that a balance needs to be struck between the use of clickers in supporting learning outcomes and the actual course content, as both vie for time in lectures (Hoffman \& Goodwin, 2006; Koppel \& Bereson, 2008). Due to the learning curve required (Koppel \& Bereson 2008), disseminating practice becomes a professional imperative (Draper 2002).

\section{Impediments to effective use of clickers in the classroom}

Whilst clear benefits do exist, there are a number of impediments to the sound pedagogical use of clickers. Misalignment of technology use and course outcomes disconnects students from the learning experience (Draper \& Brown, 2004). Likewise, there was the danger of students simply giving conditioned responses to questions rather than actually engaging in any deeper learning (Parslow, 2007; Robinson, 2007). Students have expressed negative feedback in these cases (Collins et al., 2008; d'Inverno, Davis \& White 2003; Lincoln, 2007), especially in instances where clickers have been used exclusively as attendance-polling devices (Lincoln, 2007; MacArthur \& Jones, 2008). Furthermore, when there is little connection between the learning outcomes and the clickers, students have reported 'survey fatigue', perceiving the lecture to be polling, not learning (Collins et al., 2008). This sense of fatigue may be exacerbated by possible cognitive overload caused by the inclusion of too many questions (Jensen et al, 2009). This means that the student needs to constantly refocus their attention, posing a threat to concentration and the retention of content (Mayer \& Moreno, 2003; vanMerrienboer \& Ayres, 2005;). Jensen et al. (2009) have suggested that no more than two to four questions be used per hour in order to mitigate cognitive overload.

Student learning styles need to be accounted, as some students have expressed a preference for the lecture-delivery model as this aligns more closely with their learning needs (Parslow, 2007; Trees \& Jackson, 2007). Some attribute no value to learning from their peers, instead preferring to see time allocated to expert, guest lecturer presentations (Parslow, 2007). Additionally some students have reported that clicker use simply 'forces students to listen' (Draper \& Brown, 2002), rather than engaging them in the learning process. Lastly, it needs to be acknowledged that there are instances and students for which the clickers cannot add any value (Deleo et al., 2009).

\section{Research Questions and Objectives}

The use of clickers in the information literacy class had three main objectives:

1. Establish a baseline of existing information seeking behaviour from students. 
2. Gather data about key areas of information literacy skills which had been anecdotally reported by other Librarians as consistently difficult for students to understand and apply.

3. Gather information to assess student perceptions of the use of clickers within the class.

The main objectives of this research can be expressed in three research questions:

RQ1: What are the existing information seeking behaviours of Business students attending information literacy classes?

RQ2: Is there quantitative evidence to support the anecdotal evidence concerning the consistent areas of difficulty experienced by students in searching for, and utilising information for assessment?

RQ3: How do students perceive the use of clickers to support information literacy instruction?

\section{Method}

In order to achieve the first objective, a pre-class survey was constructed. The concern had been that current information literacy instruction presumed a number of conceptual competencies which students may not have attained. Evidence from the literature concerning first-year experience, coupled with behaviours reported from lecturers evaluating assessment practice both concluded that students needed to be acculturated to the tertiary environment and the appropriate use of academic information sources formed part of this acculturation process (Goldfinch \& Hughes, 2007, p. 271; Kerr, Rynearson, \& Kerr 2006, p. 101; Nelson, Kift, Humphreys \& Harper, 2006, p. $3)$.

The initial pre-class survey was administered to 107 students, whilst the post-class survey, run at the end of semester was administered to 51 students (see Table 1.0). Most of these students were undergraduates within a first-year Information Systems course within the Faculty of Business. The pre-class surveys were conducted as part of a class run by the Faculty Librarian designed to support the development of information literacy skills within the context of the course assessment. Whilst the survey comprised both undergraduate and postgraduate students, an aggregate figure has been used due to the postgraduate sample size. Additionally, little variance existed between postgraduate responses and those of the undergraduate sample.

\begin{tabular}{|l|c|c|}
\hline \multicolumn{3}{|c|}{ Table 1.0 Summary of Survey 1 and Survey 2 responses and student groups } \\
\hline & $\begin{array}{l}\text { Survey 1 (Start of semester) } \\
\text { Administered as a pre-class survey in an } \\
\text { information literacy class to establish a } \\
\text { baseline of knowledge and behaviours. }\end{array}$ & $\begin{array}{l}\text { Survey 2 (End of semester) } \\
\text { Administered at the end of semester to } \\
\text { gauge acceptance of clickers (drawn } \\
\text { from the same respondents as Survey 1) }\end{array}$ \\
\hline $\begin{array}{l}\text { Undergraduate } \\
\text { students }\end{array}$ & 89 & 51 \\
\hline $\begin{array}{l}\text { Postgraduate } \\
\text { students }\end{array}$ & 18 & 0 \\
\hline $\begin{array}{l}\text { Total students } \\
\text { per survey }\end{array}$ & 107 & 51 \\
\hline
\end{tabular}

The pre-class survey consisted of ten questions, each directly linked to the information search tools and concepts required to complete their course assessment. The aim was to ascertain whether students were already aware of, or had a familiarity using the tools; and if not, what their main reasons were for not having utilised these tools. The data was collated and displayed using clickers and the Turning Point software, so that students were able to immediately comment on trends and also see where their response was situated in relation to their peers (Perry et al., 2002). It informed the class structure and provided a guide as to how the concepts within the IL class 
could be approached. Students were informed that all surveys were voluntary, yet the lowest participation rate was $90 \%$. Over the course of a semester, a sample of 120 students was surveyed, incorporating both first-year undergraduate and first-year postgraduate students. The convenience sampling method was utilised, with each group comprised of students attending a research skills class. Student involvement was completely voluntary, with the clickers providing anonymity of responses. Ethics Approval was obtained prior to the commencement of this study to conduct a series of surveys which were deemed by the University Ethics Committee to be of low risk to the participants. This study had institutional support through approval by the University of Southern Queensland, Faculty of Business Associate Dean (Learning and Teaching) Jane Summers and funding from the Faculty of Business's Learning and Teaching Committee. Associate Dean (Learning and Teaching) also initiated the funding for the purchase of the Keepad clicker devices and Turning point software and the associated training provided for staff wanting to use clickers in their classes.

During the project the Keepad clicker devices and TurningPoint software was used to gather the student responses. Participants in this study were students drawn from Information Systems, Marketing, Management and Business Research courses.

In relation to the second main aim of this study, key areas of difficulty concerning information literacy for students were identified via interactions with other librarians and faculty staff who reflected on the assessment submitted via prior cohorts. From this a list of desired concepts for competence were created; linked to assignment work and specific learning outcomes of the class, and then questions were formulated to informally assess students understanding of these concepts. The list covered such concepts as differentiating a journal title from an article title in a citation (and subsequently locating the full-text of the article), identifying when it is appropriate to reference, and utilising the domain name in a URL as an indicator of information type.

This use of clickers was linked to the instant feedback (Caldwell 2007; Collins et al., 2008; Deleo et al., 2009) aspect of clickers and providing learning interventions at point of need. In addition, it provided quantitative data where previously only anecdotal existed. The design of these questions was based on students actually demonstrating competency, rather than engaging in rote learning (Parslow, 2007; Trees \& Jackson, 2007). When demonstrating competency in deconstructing a citation, students were required to locate the article from an incomplete reference (which required differentiation of journal and article titles) and then subsequent questions requiring students to locate the missing parts of the citation provided.

In the last instance, students were given a short seven-question survey which utilised a seven point Likert scale. The survey was administered nine weeks after the initial class, and aimed to gauge the impact of the information literacy class upon the students' research behaviours; and their acceptance of the use of clickers. By leaving the survey late in Semester, it allowed students to practically utilise the skills developed in the class and receive feedback from assessment where these skills would have had an impact. Additionally, it mitigated the 'halo effect' (Cohen, Manion \& Morrison, 2007) which has been proven to jeopardize the integrity of survey results.

The same survey was used for all students to provide the possibility of correlation and contrast between disciplines and level of study. 


\section{Discussion of findings}

\section{RQ1: What are the existing information seeking behaviours of Business students attending information literacy classes?}

As information creation is no longer the sole province of research organisations, journals, Libraries and the like, students are able to access a wide array of information sources for the completion of assessment. As internet-based resources represent easy, often more user-friendly access to information, it is increasingly the first choice of students, especially at the undergraduate level when searching for relevant information for assignment work and projects (Rowlands et al., 2008). Students may often equate their information technology proficiency with information literacy, and may not appreciate the need to evaluate information before using it in assessment (Oliver, 2008). From an instructional perspective it is necessary to ascertain the existing student behaviours and competencies in relation to information literacy and assignment work and then ensure that the class is appropriately delivered. On a wider scope, this type of information is useful for identifying trends of behaviour which inform the design of future class content.

From the pre-class survey, most (66\%) of students used Google as their first search tool, with only $13 \%$ using a Library catalogue and 6\% utilising a database (Table 1.1). Further data (Table 1.2) suggests that of those students who had used a database, most had experienced difficulty, and had not taken full advantage of the functionality of these information resources. It was then possible to explicitly link these experiences with the learning outcomes of the class.

\begin{tabular}{|l|c|}
\hline \multicolumn{2}{|c|}{ Table 1.1 When searching for assignment information, I'd start by } \\
searching...
\end{tabular}

\begin{tabular}{|l|c|}
\hline \multicolumn{2}{|c|}{ Table 1.2 If yes (I have used a database before), indicate the one statement you most agree } \\
with.
\end{tabular}

Sixty-one percent of students had used Wikipedia to support assessment before taking the class (Table 1.3), and most (50\%) admitting that they are often not sure if the information they use if 
trustworthy, but would use it in assignment work nonetheless (Table 1.4). Whilst information evaluation is a core component of the class, it justified the usage of a Wikipedia article during this section. Students collectively established a framework of the traits of trustworthy information and then, in groups, examined a Wikipedia article against the framework. Each group reported on a single part of the framework and then judged the 'trustworthiness' of the article as a class. This task facilitated open discussion, which included the course lecturer, on the expectations of information in regards to its quality within the course.

Table 1.3 I have used Wikipedia to support assignment work before today.

\begin{tabular}{|l|c|}
\hline $\begin{array}{l}\text { 2.) I have used Wikipedia to support assignment work be- } \\
\text { fore today. }\end{array}$ & $\begin{array}{c}\text { Percentage } \\
\text { responses }\end{array}$ \\
\hline Yes & 61 \\
\hline No & 39 \\
\hline \multicolumn{2}{c}{ Total } \\
\hline
\end{tabular}

Table 1.4 Often, I'm not sure if the information I find is trustworthy (but use it anyway)

\begin{tabular}{|l|c|}
\hline $\begin{array}{l}\text { 14.) Often, I'm not sure if the information I find is trust- } \\
\text { worthy (but use it anyway) }\end{array}$ & $\begin{array}{c}\text { Percentage } \\
\text { responses }\end{array}$ \\
\hline Strongly Agree & 14 \\
\hline Agree & 36 \\
\hline Neutral & 25 \\
\hline Disagree & 16 \\
\hline Strongly Disagree & 9 \\
\hline \multicolumn{2}{c}{ Total } \\
\hline
\end{tabular}

Further questions gauged student confidence levels in their current abilities in relation to their level of information literacy and were used to focus the learning opportunities within the class to align with each class's responses. The class plan remained unchanged in all cases, but different emphasis was able to be applied depending on the results of the automatic feedback. This tailoring of the direction that a class might take based on the immediate feedback of student understanding to the instructor that clickers can provide, arguably, create a more relevant, focused class which addresses student confidence and allows the class teacher to focus on building skills in a more appropriate manner than 'one size fits all' approach.

\section{RQ2: Is there quantitative evidence to support the anecdotal evidence concerning the consistent areas of difficulty experienced by students in searching for, and utilising information for assessment?}

The sample of questions used in this section were developed at the request of the lecturer for an Information Systems course, citing that first-year undergraduates consistently had difficulty with locating suitable information for written assignments and using referencing, correctly and appropriately. The same series of questions was subsequently utilised in all IL classes delivered to undergraduate students. These students especially had difficulty in identifying the elements of a written reference. This was consistent with observations made at previous classes, but for which no quantitative evidence had been gathered. This problem statement had multiple implications for the information literacy class in that students needed to understand a reference and the given 
elements to comprehend why such information was relevant, how to actually cite within their own assessment, and how to follow a reference to the original source of the information.

The structure of an information literacy class is such that all of the learning objectives are aligned with not only the course objectives (in consultation with the relevant academic staff member) but also that each learning outcome is keyed to the Australian and New Zealand Information Literacy Framework (Bundy, 2004). The ANZIIL Standards set out six standards which define the 'information literate person' and the expected behaviours associated with each standard. Therefore, the learning outcomes associated with the ability to correctly read and construct a reference; as well as the skills demonstrated in locating an original information source from a citation are integral to information literacy instruction. Given that a majority of the students participating in this instruction were first-year undergraduates, this recognises the 'transition pedagogy' (Kift, 2009, p. 40) required to acculturate students to the tertiary learning environment. This philosophy empowers the learner by ensuring that students are explicitly given the tools and skills required to succeed in university study; rather than assuming that research and academic skills will be acquired as by-product of a university education (Chanock, 2008; Krause, 2001).

During the class (with a sample of 107 students), students were introduced to each element of a reference to a journal article. This information type was selected as it had been previously observed that students consistently mistook the article title for the journal title (or vice versa) which was an impediment to both effectively referencing sources and locating them in full-text via either the catalogue or databases.

Clickers offered a time-effective method for gathering student responses and identifying whether an intervention was required at this point. The goal was to improve student understanding of the concept and identify any difficulties in grasping it.

After an example reference had been discussed and located as a full-text article, students were presented with another reference (Table 2.1) with all of the same elements (albeit missing one author, which would be the basis for a further question).

\begin{tabular}{|l|c|}
\hline \multicolumn{2}{|l|}{$\begin{array}{l}\text { Table 2.1 :In this reference: Keizer, G 2009, 'Microsoft faces new EC } \\
\text { charges', Computerworld. vol 43, iss 4, p. 9. What is the Article title? }\end{array}$} \\
\hline $\begin{array}{l}\text { 22.) In this reference: Keizer, G 2009, 'Microsoft faces } \\
\text { new EC charges', Computerworld. vol 43, iss 4, p. 9. } \\
\text { What is the Article title? }\end{array}$ & $\begin{array}{c}\text { Percentage } \\
\text { responses }\end{array}$ \\
\hline Microsoft faces new EC charges & 80 \\
\hline Computerworld & 12 \\
\hline Vol 43, iss4 & 4 \\
\hline The article title is not provided in this reference. & 4 \\
\hline \multicolumn{1}{|c|}{ Total } & $\mathbf{1 0 0}$ \\
\hline
\end{tabular}

Whilst most students were able to correctly identify the article title (80\%), there were those who could not (16\%), and a further $4 \%$ of students who responded that the article title was not included in the reference provided. In this case, the material was able to be revisited immediately and the concept clarified. Whilst this type of question can be representative of a lower-level rotelearning query, it was necessary to utilise this style to act as a foundation upon which further tasks could be assigned, which would allow students to demonstrate their understanding of the concepts practically. 
At the next level, students were informed that one of the authors was missing from the reference (Table 2.2). They were required to locate the article, and then answer which of the authors from the list was the missing element. In this case, $92 \%$ of students were correct, $4 \%$ gave the incorrect answer where the false authors given name was the same as the correct author. The remaining $4 \%$ of students selected authors from articles in the same journal volume and issue, but not the correct article. This exercise gave the students the opportunity to demonstrate their skills, whilst the Librarian was able to observe their processes, and then test their competence.

\begin{tabular}{|c|c|}
\hline 23.) After locating the article, who is the other author? & $\begin{array}{c}\text { Percentage } \\
\text { responses }\end{array}$ \\
\hline Eric Lai & 3 \\
\hline Jeremy Kirk & 1 \\
\hline Peter Sayer & 92 \\
\hline Gary Anthes & 0 \\
\hline Peter Burrows & 4 \\
\hline Total & 100 \\
\hline
\end{tabular}

Lastly (Table 2.3), following a discussion about referencing expectations and conventions, students were asked to indicate which instances of information use required a reference. Most students (92\%) identified that all of the uses listed required a reference. Once the feedback was collated, this gave the course lecturer an opportunity to explicitly reinforce the assessment expectations with students.

Table 2.3 Which one of these information uses requires a reference?

\begin{tabular}{|l|c|}
\hline $\begin{array}{l}\text { 27.) Which one of these information uses requires a ref- } \\
\text { erence? }\end{array}$ & $\begin{array}{c}\text { Percentage } \\
\text { responses }\end{array}$ \\
\hline A direct quote from your textbook & 3 \\
\hline Information from a website from which you created a table. & 1 \\
\hline An encyclopaedia entry & 1 \\
\hline An idea (in your own words) from a journal article. & 3 \\
\hline All of the above & 92 \\
\hline \multicolumn{1}{c}{ Total } & $\mathbf{1 0 0}$ \\
\hline
\end{tabular}

\section{RQ3: How do students perceive the use of Clickers to support information literacy instruction?}

Adapting Lincoln's (2005) questionnaire for assessing attitudes to clickers, a sample of fiftyseven undergraduate students were surveyed. All participants in this sample had attended the "research skills" class earlier in the Semester and completed the survey using clickers. The survey was run at the end of the Semester, allowing students to reflect upon the class and their research practice as it related to the course. Additionally, reflection acted as a mitigating factor to responses based on the novelty of the approach.

The questions can be grouped into engagement and learning themes. From the perspective of engagement, most students (79\%) agreed that the use of clickers assisted in maintaining their attention for the class (Table 3.1); and that they made the class more enjoyable (86\%; Table 3.2). Fur- 
thermore, most (79\%) would agree that the inclusion of clickers made the class 'fun' (Table 3.4), but the authors will admit both that this is a subjective term, and question whether students seek 'fun' during an educational experience. Likewise, it is important that if attention is paid to the concept of 'fun' that it be aligned with the educational objectives of the course.

Table 3.1. The use of Clickers has helped keep my attention in this class

\begin{tabular}{|l|c|}
\hline $\begin{array}{l}\text { Use of Clickers has helped keep my attention } \\
\text { in this class }\end{array}$ & $\begin{array}{c}\text { Percentage } \\
\text { responses }\end{array}$ \\
\hline Strongly Agree & 25 \\
\hline Agree & 40 \\
\hline Somewhat Agree & 14 \\
\hline Neutral & 14 \\
\hline Somewhat Disagree & 2 \\
\hline Disagree & 2 \\
\hline Strongly Disagree & 3 \\
\hline Total & 100 \\
\hline
\end{tabular}

Table 3.2. The use of Clickers has made this class enjoyable

\begin{tabular}{|l|c|}
\hline Use of Clickers has made this class enjoyable & $\begin{array}{c}\text { Percentage } \\
\text { responses }\end{array}$ \\
\hline Strongly Agree & 25 \\
\hline Agree & 36 \\
\hline Somewhat Agree & 25 \\
\hline Neutral & 9 \\
\hline Somewhat Disagree & 2 \\
\hline Disagree & 3 \\
\hline Strongly Disagree & 0 \\
\hline Total & 100 \\
\hline
\end{tabular}

Table 3.4. Clickers are fun in this class

\begin{tabular}{|l|c|}
\hline Clickers are fun in this class & $\begin{array}{c}\text { Percentage } \\
\text { responses }\end{array}$ \\
\hline Strongly Agree & 31 \\
\hline Agree & 22 \\
\hline Somewhat Agree & 26 \\
\hline Neutral & 15 \\
\hline Somewhat Disagree & 4 \\
\hline Disagree & 2 \\
\hline Strongly Disagree & 0 \\
\hline Total & 100 \\
\hline
\end{tabular}

From a learning standpoint, most students agreed (92\%) that the clickers were simple to use (Table 3.3). 


\begin{tabular}{|l|c|}
\hline \multicolumn{2}{|c|}{ Table 3.3. Clickers are easy to use in this class } \\
\hline Clickers are easy to use in this class & $\begin{array}{c}\text { Percentage } \\
\text { responses }\end{array}$ \\
\hline Strongly Agree & 72 \\
\hline Agree & 20 \\
\hline Somewhat Agree & 0 \\
\hline Neutral & 0 \\
\hline Somewhat Disagree & 0 \\
\hline Disagree & 2 \\
\hline Strongly Disagree & 6 \\
\hline Total & 100 \\
\hline
\end{tabular}

This could support the position that the devices are well-integrated with the course and did not require much user instruction. However, the fact that some students responded negatively ( $8 \%)$ does give cause for further investigation. As this survey will be used in future years as part of a longitudinal study, qualitative tools will be built into future research to gather more explanatory data. A majority of students (60\%) believed that the clickers assisted in learning key concepts, which had been presented at the beginning of the class (See Table 3.5). Again, this dispersal of results would require follow-up interviews or focus groups to determine why negative results were received. This could be explained via preferences in learning style, the actual use of the clickers by the Librarian and how well the aligned with the key learning outcomes, or other factors. The same dispersal occurred regarding students agreement that the use of clickers to learn the concepts presented would improve their final grade (Table 3.6). 48\% students agreed, making it the lowest agreement on any question. There were $19 \%$ students who responded neutrally, which was consistent with those giving the same response to learning key concepts (17\%). In the last question (Table 3.7), most students ( $73 \%$ ) would welcome the use of clickers in other classes. Interestingly, whilst in previous questions, students had reported lower satisfaction with the support clickers offered in learning key concepts and scepticism regarding the correlation between clicker use and improved grades; they wanted to see their use become more widespread in other undergraduate courses. Therefore, it would appear that, overall, students felt that they benefitted from the use of clickers in supporting their learning.

\begin{tabular}{|l|c|}
\hline \multicolumn{2}{|c|}{ Table 3.5. Use of Clickers has helped me to learn key principles in } \\
this class
\end{tabular}




\begin{tabular}{|l|c|}
\hline \multicolumn{2}{|c|}{$\begin{array}{c}\text { Table 3.6. Clickers used for the duration of this class would help im- } \\
\text { prove my overall final grade }\end{array}$} \\
\hline $\begin{array}{l}\text { Clickers used for the duration of this class } \\
\text { would help improve my overall final grade }\end{array}$ & $\begin{array}{c}\text { Percentage } \\
\text { responses }\end{array}$ \\
\hline Strongly Agree & 2 \\
\hline Agree & 24 \\
\hline Somewhat Agree & 22 \\
\hline Neutral & 19 \\
\hline Somewhat Disagree & 11 \\
\hline Disagree & 7 \\
\hline Strongly Disagree & 15 \\
\hline Total & 100 \\
\hline
\end{tabular}

\begin{tabular}{|l|c|}
\hline \multicolumn{2}{|c|}{ Table 3.7 I would like to see the use of Clickers in more of my classes } \\
\hline $\begin{array}{l}\text { I would like to see the use of Clickers in more } \\
\text { of my classes }\end{array}$ & $\begin{array}{c}\text { Percentage } \\
\text { responses }\end{array}$ \\
\hline Strongly Agree & 30 \\
\hline Agree & 26 \\
\hline Somewhat Agree & 17 \\
\hline Neutral & 15 \\
\hline Somewhat Disagree & 0 \\
\hline Disagree & 4 \\
\hline Strongly Disagree & 8 \\
\hline Total & 100 \\
\hline
\end{tabular}

Scope exists for further study regarding whether students' perception of the number and frequency of the questions posed can identify more effective ways of utilising clickers, and whether these questions and the corresponding feedback identified learning opportunities. Furthermore, responses to the anonymity of feedback, and the ability to 'benchmark' learning against one's peers represent avenues for future study.

\section{Implications}

The findings of this study suggest that the use of clickers provided an effective and efficient means to actively engage and facilitate student learning in an information literacy class Using clickers allowed the teacher to collect quantitative data to establish a baseline of student understanding and competencies of information literacy in relation to information searching and referencing which is critical for assignment work. Furthermore the use of clickers allowed the teacher to provide immediate feedback to students in relation to information literacy in the context of information searching and correct referencing for written assignment work.

The data collected from the use of clickers in this study lends support to the findings of previous studies of information literacy of University students (Kennedy, Judd, Churchward, \& Gray, 2008; MacPherson, 2002; Perrin, Hossain, \& Cumming, 2008) and in particular first year students which have found that these students experience difficulty in locating and assessing the quality of information available on the Internet and online databases and correctly interpreting the key elements of referencing to assist them in their information searching and written assignment work. 
Moreover it does appear, from this data, that the appropriate use of clickers does act as a facilitator for active learning pedagogies, in that the surveyed students did feel more engaged with the lecture, and most believed that the use of the devices assisted in their learning experience during class lectures and tutorials. The findings of the survey regarding student perceptions of the devices are that students found that the use of clickers by the lecturer held their attention more effectively, that this technology made the class more enjoyable and interactive and that students would like to see these devices used more widely in other undergraduate and postgraduate courses. However, the authors do stress the term 'appropriate use'. Clickers will not be relevant to all courses, or even all lectures within a single course, and learning objectives need to be aligned with the principles of active learning in the selection and design of clicker questions for deep learning to occur.

The clickers were rated as 'easy to use' by a majority of students, but more probing questions will be required to ascertain if students experienced any difficulties in processing information supported by clicker questions. During the classes, response rates of over $90 \%$ were experienced to the questions and tasks posed. Whilst the implications of cognitive load theory in this area may represent avenues for future investigation and explanation, it may be more relevant to multimedia tutorials and presentations, as opposed to the use of clickers. Cognitive overload, as previously defined, occurs when auditory or visual channels within the brain are 'overloaded', and that information overload on one channel cannot be transferred to the other (Mayer \& Moreno, 2003, p. 45). It could be postulated that in most cases, clickers do not contribute to cognitive overload, as the same message is delivered in parallel to both the auditory and visual channels. That is, the question or task described by the lecturer needs to be the same as the question or task described visually by the PowerPoint presentation. Little to no disconnect or misalignment between the oral and textual representations will reduce the impact upon cognitive loads. One of the limitations is that the clickers were used twice during the semester, in terms of information literacy instruction. It was a concern that students may have responded favourably due to the "novelty factor' associated with the devices. However one of the authors used them for an entire semester during most lectures and found similar levels of acceptance of the use of clickers. The implications for future practice point towards the development of a deeper understanding of how to more effectively utilise clickers to meet learning objectives for information literacy instruction within the Business curriculum. The data gathered by administering the prior knowledge test (Tables 1.1-1.4) can be integrated into the class redesign for subsequent semesters, and a longitudinal application of this survey can establish consistent trends. In addition, the exploration into the automatic feedback applications of clickers has justified the prior anecdotal evidence and observations gathered during information literacy classes. The use of the data gathered from the inclass tests, therefore, serve a similar function to the prior knowledge test in the design of future classes; and the goal of improving student understanding and application of class content.

Finally, this research has identified the role of diffusion of practice in the use of clickers and building a collaborative understanding of their use and seeking 'best practice'. By sharing experiences at a faculty, institutional or broader level, it is possible to collectively build both underpinning knowledge of, and the application of practice for, the more effective and efficient use of this technology to support and enhance learning.

\section{Conclusions}

This study represents a quantitative approach to investigating the effectiveness of clickers in investigating and improving information literacy of business students. The use of clickers allowed the teacher to effectively establish a baseline of students understanding of information literacy in relation to information searching, correct referencing in assignment work. This activity through the use of clickers allowed the students get immediate feedback on their current level of informa- 
tion literacy and the trustworthiness of information obtained on the Internet via a search engine such as Google and Wikipedia versus the library online databases. The use of clickers also allowed the teacher to establish students' levels of key information literacy competencies such as being able to fully comprehend a journal article reference and how to reference correctly while at the same time providing immediate feedback to students on these information literacy activities. Moreover students surveyed perceived the use of clickers positively in terms of facilitating their active engagement and learning of key principles in the information literacy class. Students also indicated overwhelmingly that clickers were easy and fun to use.

There is further scope for corroborating or explanatory qualitative studies to better understand how and why clickers can facilitate active learning and participation in undergraduate courses, and these mechanisms will be designated to future studies. Additionally, whilst some authors have indicated that the use of clickers as primarily benefitting Millennial students (Caldwell 2007; Dill, 2008;) which are categorised as the current generation of students entering University via secondary school; which aligns with prevailing discussions regarding technology-enhanced learning and engagement. The authors would like to collect cross-indexed demographic data to test this assertion across a broad range of undergraduate students. It has been observed that students within the Faculty of Business are drawn from a diverse range of cultures and age groups thus it would be possible to examine clicker use (provided a large enough representative sample could be located) against these demographic indicators.

Likewise, qualitative data should be sought during subsequent semesters, to probe and gain a better understanding of the how and why questions arising from this initial data set. In future years it will be necessary to separate the responses of those who have previously used clickers to those experiencing them for the first time - parallel data sets could be used to investigate whether opinions change after longer exposure to the use of the devices.

\section{References}

Beatty, I. (2004). Transforming student learning with classroom communication systems. ECAR, 3, 1-13.

Beatty, I. (2006). Designing effective questions for classroom responses system teaching. American Journal of Physics, 74(1), 31-38.

Beekes, W. (2006). The 'millionaire' method for encouraging participation. Active Learning in Higher Education, 7(1), 25-36.

Bergtrom, G. (2006). Clicker sets as learning objects. Interdisciplinary Journal of Knowledge and Learning Objects, 2, 105-110. Retrieved from http://www.ijello.org/Volume2/v2p105-110Bergtrom.pdf

Boudreau, S., \& Bicknell-Holmes, T. (2003). A model for strategic business instruction. Research Strategies, 19(2), 149-162.

Bundy, A. (2004). Australian and New Zealand information literacy framework: Principles, standards and practice. Retrieved 12th December, 2009, from http://citeseerx.ist.psu.edu/viewdoc/download?doi=10.1.1.98.3489\&rep=rep1\&type=pdf

Caldwell, J. (2007). Clickers in the large classroom: Current research and best-practice tips. Cell Biology Education, 6, 9-20.

Campbell, A., \& Norton, L. (Eds). (2007). Learning, teaching and assessing in higher education: Developing reflective practice. United Kingdom: Learning Matters.

Chanock, K. (2008). When students reference plagiarised material - what can we learn (and what can we do) about their understanding of attribution? International Journal for Educational Integrity, 4(1), 316.

Cohen, L., Manion, L., \& Morrison, K. (2007). Research methods in education (6th ed.). USA: Routledge. 
Collins, B.; Tedford, R.; \& Womack, D. (2008). 'Debating' the merits of clickers in an academic library. North Carolina Libraries, 66, 20-24.

Department of Education, Science and Training (DEST) (2007). Graduate employability skills: prepared for the Business, Industry and Higher Education Collaboration Council. Retrieved 17 November 2009 from http://www.dest.gov.au/NR/rdonlyres/E58EFDBE-BA83-430E-A5412E91BCB59DF1/20214/GraduateEmployabilitySkillsFINALREPORT1.pdf

Deloe, P.; Eichenholtz, S.; \& Sosin, A. (2009). Bridging the information literacy gap with clickers. The Journal of Academic Librarianship, 35(5), 438-444.

Dill, E. (2008). Do clickers improve library instruction? Lock in your answers now. Journal of Academic Librarianship, 34(6), 527-529.

d'Inverno, R., Davis, H., \& White, S. (2003). Using a personal response system for promoting student interaction. Teaching Mathematics and Its Applications, 22(4), 163-169.

Draper, S. (2002). Evaluating effective use of PRS: results of the evaluation of the use of PRS in Glasgow University. Retrieved 20 November 2009 from www.psy.gla.ac.uk/ steve/ilig/papers/eval.pdf

Draper, S., \& Brown, M. (2002). Use of the PRS (Personal Response System) handsets at Glasgow University: Interim evaluation report March 2002. Retrieved 20 November 2009 from http://www.psy.gla.ac.uk/ steve/ilig/interim.html

Draper, S., \& Brown, M. (2004). Increasing interactivity in lecturers using an electronic voting system. Journal of Computer Assisted Learning, 20, 81-94.

Drucker, P. (1995). The information executives truly need Harvard Business Review, 73(1), 55-62.

Feast, V. 2003. Integration of information literacy skills into business courses. Reference Services Review, $31(1), 81-95$.

Goldfinch, J. \& Hughes, M. (2007). Skills, learning styles and success of first-year undergraduates. Active Learning in Higher Education, 8(3), 259-273

Grimm, P.; Soares, E.; Agrawal, J.; \& Law, S. (2007). Technology facilitated class participation in a principles of marketing course. Proceedings of the 2007 ANZMAC Conference, 3287-3292.

Gross, M. \& Latham, D. 2007. Attaining information literacy: An investigation of the relationship between skill level, self-estimates of skill, and library anxiety. Library and Information Science Research, 29, 332-353.

Hatch, J.; Jensen, M.; \& Moore, R. (2005). Manna from heaven or 'clickers' from hell. Journal of College Science and Teaching, July/August, 36-39.

Hoffman, C.; \& Goodwin, S. (2006). A clicker for your thoughts. New Library World, 107(1228/1229), 422-433.

Jacobson, T., \& Xu, L. (2004). Motivating students in information literacy classes. New York: NealSchuman.

Jensen, R.; Meyer, L.; \& Sternberger, C. (2009). Three technological enhancements in nursing education: informatics instruction, personal response systems, and human patient simulation. Nurse Education in Practice, 2009(9), 86-90.

Johnston, B., \& Webber, S. (2006). As we may think: Information literacy as a discipline for the information age. Research Strategies, 20, 108-121.

Judson, E., \& Sawada, D. (2002). Learning from past and present: Electronic response systems in college lecture halls. Journal of Computers in Mathematics and Science Teaching, 21(2), 167-181.

Keepad Interactive. (2010). Audience response systems. Retrieved from http://www.keepad.com/turningpoint.php 
Kennedy, G. E., Judd, T. S., Churchward, A., \& Gray, K. (2008). First year students' experiences with technology: Are they really digital natives? Australasian Journal of Educational Technology, 24(1), 108-122.

Kerr, M., Rynearson, K., \& Kerr, M. (2006). Student characteristics for online learning success. The Internet and Higher Education, 9, 91-105.

Kift, S. (2009). Articulating a transition pedagogy to scaffold and to enhance the first year student learning experience in Australian higher education: Final report for ALTC senior fellowship program. Retrieved from http://www.altc.edu.au/resource-first-year-learning-experience-kift-2009

Kikoski, C.; \& Kikoski, J. (2004). The inquiring organisation: Tacit knowledge, conversation, and knowledge creation: Skills for $21^{\text {st }}$-century organisations. London: Praeger.

Kocevar-Weidinger, E., \& Cooperstein, S. (2003). Beyond active learning: A constructivist approach to learning. Reference Services Review, 32(2), 141-148.

Koppel, N.; \& Berenson, M. (2008). Ask the audience... using clickers to enhance introductory business statistics courses. Proceedings of the Information Systems Education Conference, 1-15.

Krause, K. (2001). The university essay writing experience: A pathway for academic integration during the transition. Higher Education Research and Development, 20(2), 147-168.

Lincoln, D. (2007). Using student response pads ('clickers') in the principles of marketing classroom. Proceedings of the 2007 ANZMAC Conference, 3328-3333.

MacArthur, J.; \& Jones, L. (2008). A review of literature reports of clickers applicable to college chemistry classrooms. Chemistry Education Research and Practice, 9, 187-195.

MacPherson, K. (2002). PhD Thesis: The development of enhanced information retrieval strategies in Undergraduates through application of learning theory: an experimental study. University of Canberra, Canberra.

Mayer, R.; \& Moreno, R. (2003). Nine ways to reduce cognitive overload in multimedia learning. Educational Psychologist, 38(1), 43-52.

Mula, J., \& Kavanagh, M. (2009). Click Go the Students, Click-Click-Click: The efficacy of a student response system for engaging students to improve feedback and performance. e-Journal of Business Education \& Scholarship of Teaching, 3(1), 1-17.

Nelson, K.., Kift, S., Humphreys, J., \& Harper, W. (2006). A blueprint for enhanced transition: Taking an holistic approach to managing student transition into a large university. Proceedings First Year in Higher Education Conference, Australia: QUT.

O'Donoghue, J., \& Maguire, T. (2005). The individual learner, employability and the workplace: A reappraisal of relationships and prophecies. Journal of European Industrial Training, 29(6), 436-446.

Oliver, B. (2008). 'Commencing undergraduates' self-efficacy and ability in finding academic resources: Are they improving?' Studies in Learning, Evaluation, Innovation and Development, 5(3), 1-8.

Parslow, G. (2007). Clickers (personal response units) may add value to lectures. Biochemistry and Molecular Biology Education, 35(2), 156-157.

Perrin, C., Hossain, D., \& Cumming, K. (2008, 16-19 June). Nursing students' information literacy skills prior to and after information literacy instruction. 5th International Lifelong Learning Conference: Reflecting on Successes and Framing Futures, Yeppoon, Australia.

Perry, N., VandeKamp, K., Mercer, L., \& Nordby, C. (2002). Investigating teacher-student interactions that foster self-regulating learning. Educational Psychologist, 37(1), 5-15.

Reece, G. (2007). Critical thinking and cognitive transfer: Implications for the development of online information literacy tutorials. Research Strategies, 20, 482-493.

Robinson, S. (2007). Games, clickers and study habits: increasing students' motivation to study and participate. Management Review: An International Journal, 2(2), 98-111. 
Rowlands, I., Nicholas, D., Williams, P., Huntington, P. Fieldhouse, M., Gunter, B., Withey, R., Jamali, H., Dobrowolski, T., \& Tenopir, C. (2008). The Google generation: The information behaviour of the researcher of the future. Aslib Proceedings: New Information Perspective, 60(4), 290-310.

Simpson, V., \& Oliver, M. (2006). Using electronic voting systems in lectures. Retrieved 20 November 2009 from www.ucl.ac.uk/learningtechnology/examples/electronicvoting systems.pdf

Tanner, K., \& Allen, D. (2005). Approaches to biology teaching and learning: Understanding the wrong answers - teaching toward conceptual change. Cell Biology Education, 4, 112-117.

Trees, A.; \& Jackson, M. (2007). The learning environment in clicker classrooms: Student processes of learning and involvement in large university-level courses using student response systems. Learning, Media and Technology, 32(1), 21-40.

vanMerienboer, J., \& Ayres, P. (2005). Research on cognitive load theory and its design implications for elearning. Educational Technology Research and Development, 53(3), 5-13.

Weetman, J. (2005). Osmosis - Does it work for the development of information literacy? The Journal of Academic Librarianship, 31(5), 456-460.

Weisskirch, R., \& Silveria, J. (2007). The effectiveness of project-specific information competence instruction. Research Strategies, 20, 370-378.

Wu, Y., \& Kendall, S. (2005). Teaching faculty's perspectives on business information literacy. Reference Services Review, 34(1), 86-96.

\section{Biographies}

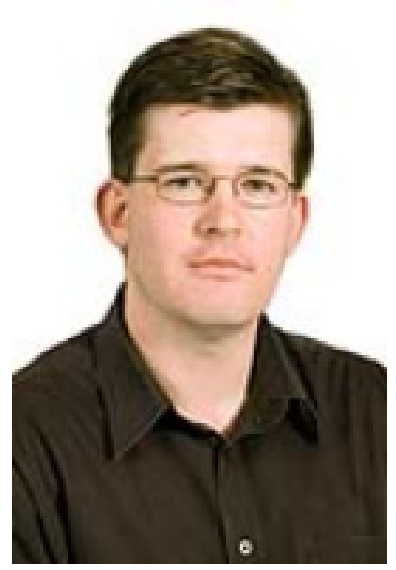

Adrian Stagg is the Faculty of Business Librarian at the University of Southern Queensland. He has a Bachelor of Arts from Charles Sturt University and he is currently completing a Master of Applied Science with Charles Sturt University. Adrian's research is concentrated in the areas of Information literacy and Technology enhanced learning.

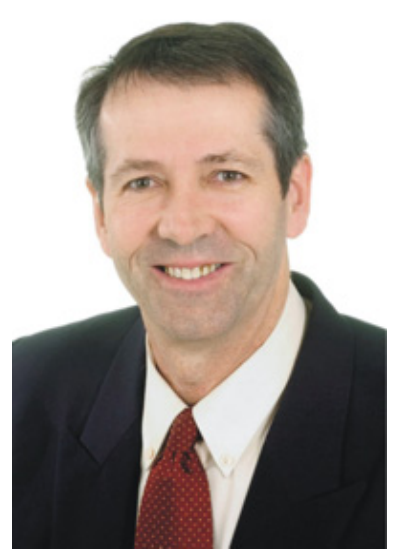

Dr Michael Lane is a Senior Lecturer in the School of Information Systems in the Faculty of Business at University of Southern Queensland. He has a PhD in Information Systems from the University of Southern Queensland. Michael's research is concentrated in the areas of Information systems education and technology enhanced learning and strategic management of ICT including sustainable use of ICT, the changing role of chief information officer (CIO), information security management, wireless and mobile computing. 